\title{
Flow and Storage in Groundwater Systems
}

\author{
William M. Alley, ${ }^{1 *}$ Richard W. Healy, ${ }^{2}$ James W. LaBaugh, ${ }^{1}$ Thomas E. Reilly ${ }^{1}$
}

The dynamic nature of groundwater is not readily apparent, except where discharge is focused at springs or where recharge enters sinkholes. Yet groundwater flow and storage are continually changing in response to human and climatic stresses. Wise development of groundwater resources requires a more complete understanding of these changes in flow and storage and of their effects on the terrestrial environment and on numerous surface-water features and their biota.

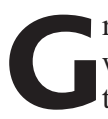
roundwater is a crucial source of fresh water throughout the world. More than 1.5 billion people worldwide (1) and more than $50 \%$ of the population of the United States (2) rely on groundwater for their primary source of drinking water. Groundwater is an essential part of the hydrologic cycle (Fig. 1) and is important in sustaining streams, lakes, wetlands, and aquatic communities.

During the past 50 years, groundwater depletion has spread from isolated pockets to large areas in many countries throughout the world. Prominent examples include the High Plains of the central United States, where more than half the groundwater in storage has been depleted in some areas, and the North China Plain, where depletion of shallow aquifers is forcing development of deep, slowly replenished aquifers with wells now reaching more than $1000 \mathrm{~m}$ (3). Groundwater depletion may be the single largest threat to irrigated agriculture, exceeding even the buildup of salts in soil (3). In arid regions, much of the groundwater removed from storage today was recharged during wetter conditions in the last ice age, causing further concerns about present withdrawal rates. Global groundwater depletion has been appreciable enough to contribute to sea-level rise during the past century as a result of water pumped from wells that returns to the sea either by runoff or by evapotranspiration followed by precipitation (4).

Many unfamiliar with its dynamic nature view groundwater as a static reservoir. Even specialists may overlook its linkages across the biosphere and consider it an isolated part of the environment (5). Yet, as discussed below in general terms and through examples, the dynamic aspects of groundwater flow systems, their recharge, and interactions

${ }^{1}$ U.S. Geological Survey, 411 National Center, Reston, VA 20192, USA. ${ }^{2}$ U.S. Geological Survey, Post Office Box 25046, Mail Stop 413, Denver Federal Center, Lakewood, CO 80225, USA.

*To whom correspondence should be addressed. Email:walley@usgs.gov with surface water and the land surface are numerous and extend over many different time scales.

\section{Dynamics of Groundwater Flow Systems}

A groundwater system comprises the subsurface water, the geologic media containing the water, flow boundaries, and sources (such as recharge) and sinks (such as springs, interaquifer flow, or wells). Water flows through and is stored within the system. Under natural conditions, the travel time of water from areas of recharge to areas of discharge can range from less than a day to more
Pools are in cubic kilometers

Fluxes are in cubic kilometers per year publisher, Elsevier Science (USA)] than a million years $(6)$. Water stored within the system can range in age (7) from recent precipitation to water trapped in the sediments as they were deposited in geologic time.

The variability of aquifer response times is illustrated by the time required for the hydraulic head (water levels) in a groundwater system to approach equilibrium after some hydraulic perturbation, such as well pumping or a change in recharge rate. This can be estimated for confined groundwater systems (8) as

$$
T^{*}=S_{\mathrm{s}} L_{\mathrm{c}}{ }^{2} / K
$$

where $T^{*}$ is the hydraulic response time $(T)$ for the basin, $S_{\mathrm{s}}$ is specific storage $\left(L^{-1}\right), L_{\mathrm{c}}$ is some characteristic length $(L)$ of the basin, and $K$ is hydraulic conductivity $(L / T)$. The hydraulic conductivity, a measure of permeability, can range over 12 orders of magnitude (8), and the distance between boundaries of groundwater systems can range from meters to hundreds of kilometers. Using Eq. 1 , hydraulic response times calculated for two idealized systems $(9)$ are 0.1 day (144 $\min )$ for horizontal flow in a confined streamaquifer system and $4.0 \times 10^{7}$ days $(110,000$ years) for vertical flow in a thick regional low-permeability unit.

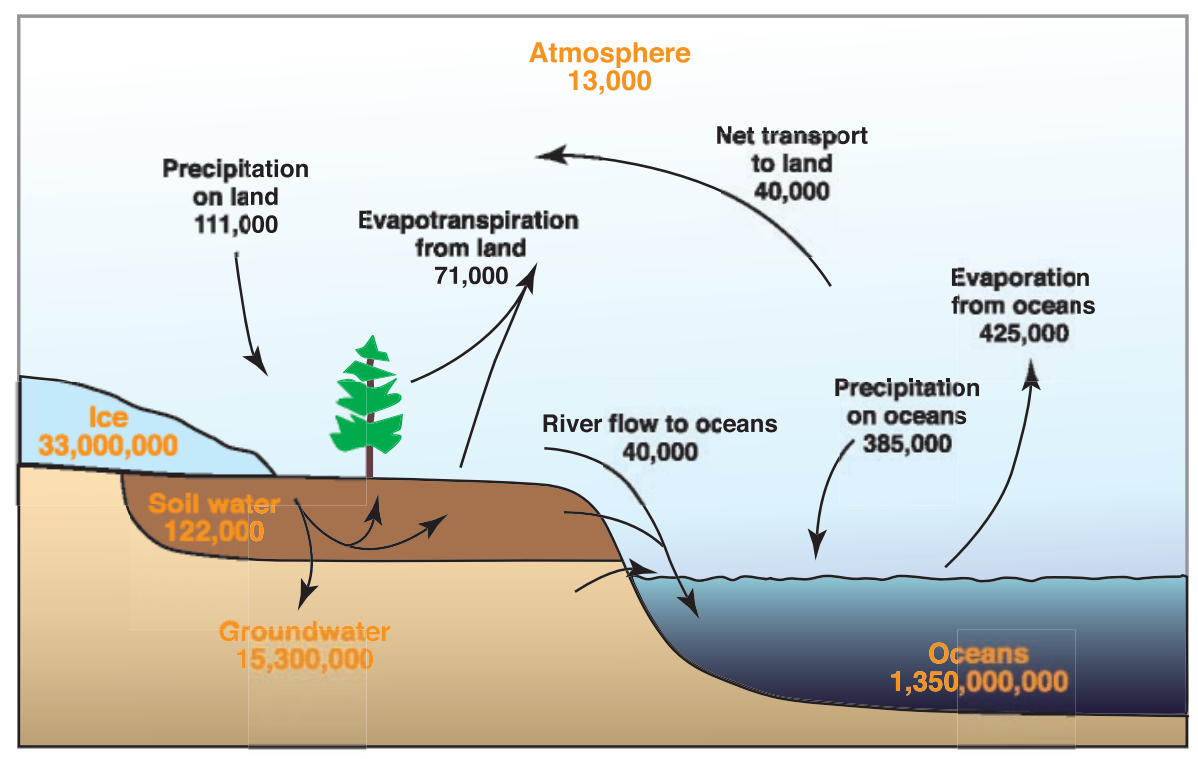

Fig. 1. Global pools and fluxes of water on Earth, showing the magnitude of groundwater storage relative to other major water storages and fluxes. [Reproduced from (82) with permission from the

The time of travel through the system depends on the spatial and temporal gradients of hydraulic head, hydraulic conductivity, and porosity of the system. The time of travel through a system is different from the hydraulic response time to approach 


\section{SCIENCE'S COMPASS}
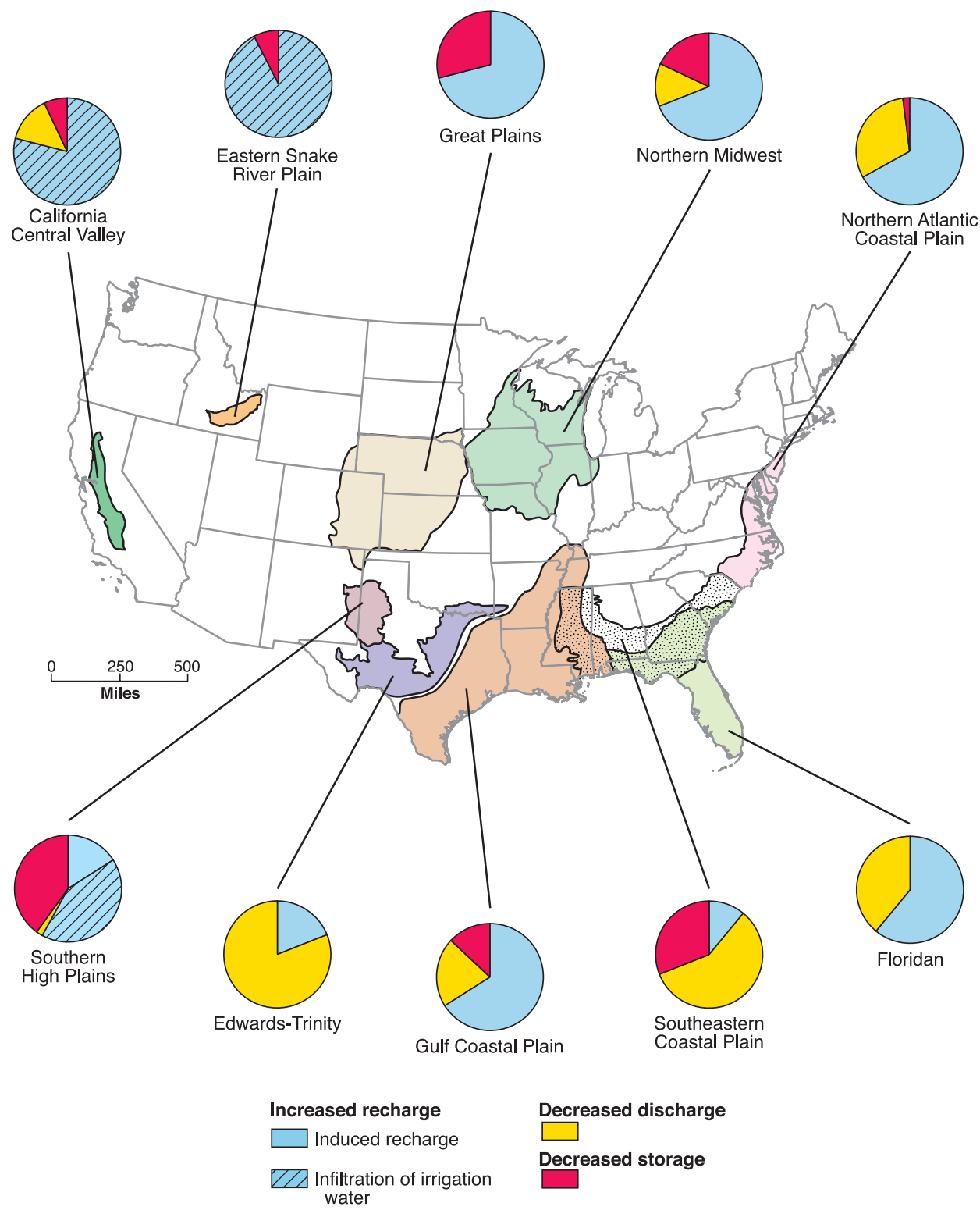

Fig. 2. Sources of water that supply withdrawals from major aquifer systems in the United States are highly variable, as shown by these results from model simulations for various periods (83). The Floridan and Edwards-Trinity aquifer systems, which equilibrate rapidly after pumping, were simulated as steady-state with no long-term change in storage. In contrast, the Southern High Plains (with most natural discharge occurring far from pumping wells) and the deeply buried Great Plains aquifer system have had substantial changes in groundwater storage. The distinction between changes in recharge and changes in discharge is a function of how the system was defined (i.e., a gain to one system may result in a loss from an adjoining system). For example, groundwater withdrawals from confined aquifers (Northern Atlantic Coastal Plain, Gulf Coastal Plain) can cause flow to be diverted (recharged) into the deeper regional flow regime that would otherwise discharge to streams in the outcrop areas or cause vertical leakage across confining units. Groundwater recharge in a region can be increased as a result of human modifications, such as return flow of excess irrigation water (California Central Valley). Note that the areal extent of the Southeastern Coastal Plain aquifer system overlaps the areal extents of the Floridan and Gulf Coastal Plain aquifer systems.

equilibrium. For example, it was calculated above that the hydraulic head in the confined stream-aquifer system responded to a perturbation in less than a day; however, the time required for water to move through the entire width of the system is on the order of 30,000 days (82 years) under natural conditions (10). Fractured-rock systems in bedrock usually have smaller effective porosities than unconsolidated porous media systems such as sands and gravels, and flow velocities through fractured-rock systems can be relatively fast (11). For example, travel times of water over distances of several kilometers have been estimated at less than a year for municipal wells completed in fractured dolomite in Wisconsin (12). Seasonal variations in recharge and pumping affect the variability in travel times in such cases. In more sluggish groundwater systems, such as the Bangkok Basin in Thailand (13), long-term climate and geologic change need to be considered in understanding the movement of groundwater over tens of thousands of years. The longterm movement of groundwater also influences virtually all geologic processes (14, 15), including diagenesis, ore mineralization, and petroleum accumulation.

The time of travel of water is important in determining the movement of contaminants within a groundwater system. The large extent of groundwater contamination worldwide from surface sources reflects the fact that shallow groundwater ages are typically a few decades or less. Hydraulic gradients caused by large-capacity wells can further reduce the travel times of contaminants to wells (16).

Water withdrawn from a groundwater system initially comes from storage. Over time, the effects of the withdrawal are propagated through the system as heads decrease at greater distances from the point of withdrawal. Ultimately, the effect of the withdrawal reaches a boundary (such as a stream) where either increased recharge to the groundwater system or decreased discharge from the system occurs. The common assumption that the rate of groundwater withdrawal is "safe" or "sustainable" if it does not exceed the natural rate of recharge is not correct, because it ignores these changes in discharge from and recharge to the groundwater system $(17,18)$. The sources of water supplying pumpage from 10 major regional aquifer systems in the United States are shown in Fig. 2. These illustrate the variability of aquifer response to long-term pumping and the extent to which changes in recharge and discharge can exceed changes in storage.

Computer models of flow and solute transport have been integral tools for evaluation of groundwater resources for many years; they have been applied to a wide range of problems, from local contamination to the origin of large mineral bodies from continental-scale fluid migrations (19). The predictive capability of models permits hypothesis testing, which enhances our understanding of current conditions, as well as forecasting of aquifer response to future climatic or anthropogenic stresses. Recent linkages of groundwater flow models with land surface-atmosphere models (20) and of transport models with geochemical reaction models (21) have extended the types of problems that can be addressed. Automatic calibration schemes and uncertainty analysis (22) have enhanced model application, 


\section{SCIENCE'S COMPASS}

and new computer visualization tools have advanced our understanding of the effects of variability in aquifer properties on groundwater flow patterns.

Accuracy of model predictions is constrained by the correctness of the model (i.e., proper representation of relevant processes) and uncertainty in model parameters. The latter uncertainty is due to the limited accuracy with which parameter values can be measured and, more important, to the substantial heterogeneity inherent in aquifer characteristics. The inability to describe and represent this heterogeneity adequately is a fundamental problem in groundwater hydrology and will continue, even with improved models, to place limits on the reliability of model predictions. The links between spatial heterogeneity and model uncertainty also depend on the type of questions being asked. For example, reasonable estimation of head distributions in an aquifer may require only limited understanding of spatial heterogeneity. On the other hand, confidence in predictions of chemical concentrations at a specific location can be very sensitive to minor uncertainty in the spatial distribution of hydraulic properties, even for relatively homogeneous porous media.

Tracer techniques have been widely applied for estimating the residence time of subsurface waters, as well as the amounts and timing of recharge and discharge (23). Most tracer techniques require knowledge (or assumption) of the time history of tracer application at the land surface or the water table (Fig. 3). This temporal pattern is then correlated to a concentrationdepth pattern in the subsurface at a point in time. Other approaches [e.g., the ${ }^{3} \mathrm{H} /{ }^{3} \mathrm{He}$ technique (24)] use information on decay products to determine age. Tracers can be naturally occurring (the stable isotopes ${ }^{2} \mathrm{H}$ and ${ }^{18} \mathrm{O}, \mathrm{Cl}$, heat), can occur in the atmosphere as a result of anthropogenic activities [tritium, ${ }^{36} \mathrm{Cl}$, chlorofluorocarbons (CFCs)], or can be applied intentionally on the land surface ( $\mathrm{N}$ and $\mathrm{P}$ fertilizers, organic pesticides). Isotopes of elements dissolved from host rocks $\left({ }^{222} \mathrm{Rn},{ }^{87} \mathrm{Sr} /{ }^{86} \mathrm{Sr}\right)$ can also be used to estimate residence times and interactions with surface water.
Over the past decade, advances in age dating and tracking young groundwater ( $<50$ years old) using multiple tracers have been major breakthroughs in understanding the dynamics of groundwater systems. For example, multiple tracers have been used to define the amount and locations of river water recharging the Upper Floridan aquifer and causing deterioration of well-water quality near Valdosta, Georgia (25), to constrain groundwater flow models in the Atlantic Coastal Plain (26), and to help explain unusual nutrient regimes from groundwater inputs to Florida Bay (27).

quantify. The present discussion is limited to recharge to the water table (as opposed to interaquifer recharge). Recharge can occur in response to individual precipitation events in regions having shallow water tables. In contrast, unsaturated zone water in some desert regions is estimated to have infiltrated the soil surface as long as 120,000 years ago (29). Perhaps nowhere is the importance and difficulty of estimating recharge more apparent than in the assessment of the suitability of Yucca Mountain, Nevada, as a repository for high-level radioactive waste. More than 15 years and tens of millions of dollars have been spent to estimate recharge rates and locations through the thick, fractured volcanic tuffs at this site under past, current, and future climates (30).

Recharge can be diffuse or localized. Diffuse recharge refers to the widespread movement of water from land surface to the water table as a result of precipitation over large areas infiltrating and percolating through the unsaturated zone. Localized recharge refers to the movement of water from surfacewater bodies to the groundwater system and is less uniform in space than diffuse recharge. Most groundwater systems receive both diffuse and localized recharge. In general, the importance of diffuse recharge decreases as the aridity of a region increases (31). For example, in semiarid parts of Niger, localized recharge from naturally occurring runoff-collection ponds accounts for virtually all recharge (32).

Typically, most water from precipitation that infiltrates does not become recharge. Instead, it is stored in the soil zone and is eventual-

Determining the time that water has been flowing within the groundwater system is particularly useful in understanding the operation of highly heterogeneous aquifer systems. However, special care should be taken in interpretations of tracer concentrations in these settings, because the concentrations may be affected greatly by hydrodynamic dispersion and diffusion into the rock matrix (28).

\section{Recharge}

Recharge is an important factor in evaluating groundwater resources but is difficult to ly returned to the atmosphere by evaporation
and plant transpiration. The percentage of precipitation that becomes diffuse recharge is highly variable, being influenced by factors such as weather patterns, properties of surface soils, vegetation, local topography, depth to the water table, and the time and space scales over which calculations are made. For example, over a 6-year period, recharge in the Great Bend area of central Kansas was estimated to be $10 \%$ of the annual precipitation of $585 \mathrm{~mm}$; however, in some years, no recharge occurred (33).

Magnitudes of recharge fluxes are gen- 


\section{SCIENCE'S COMPASS}

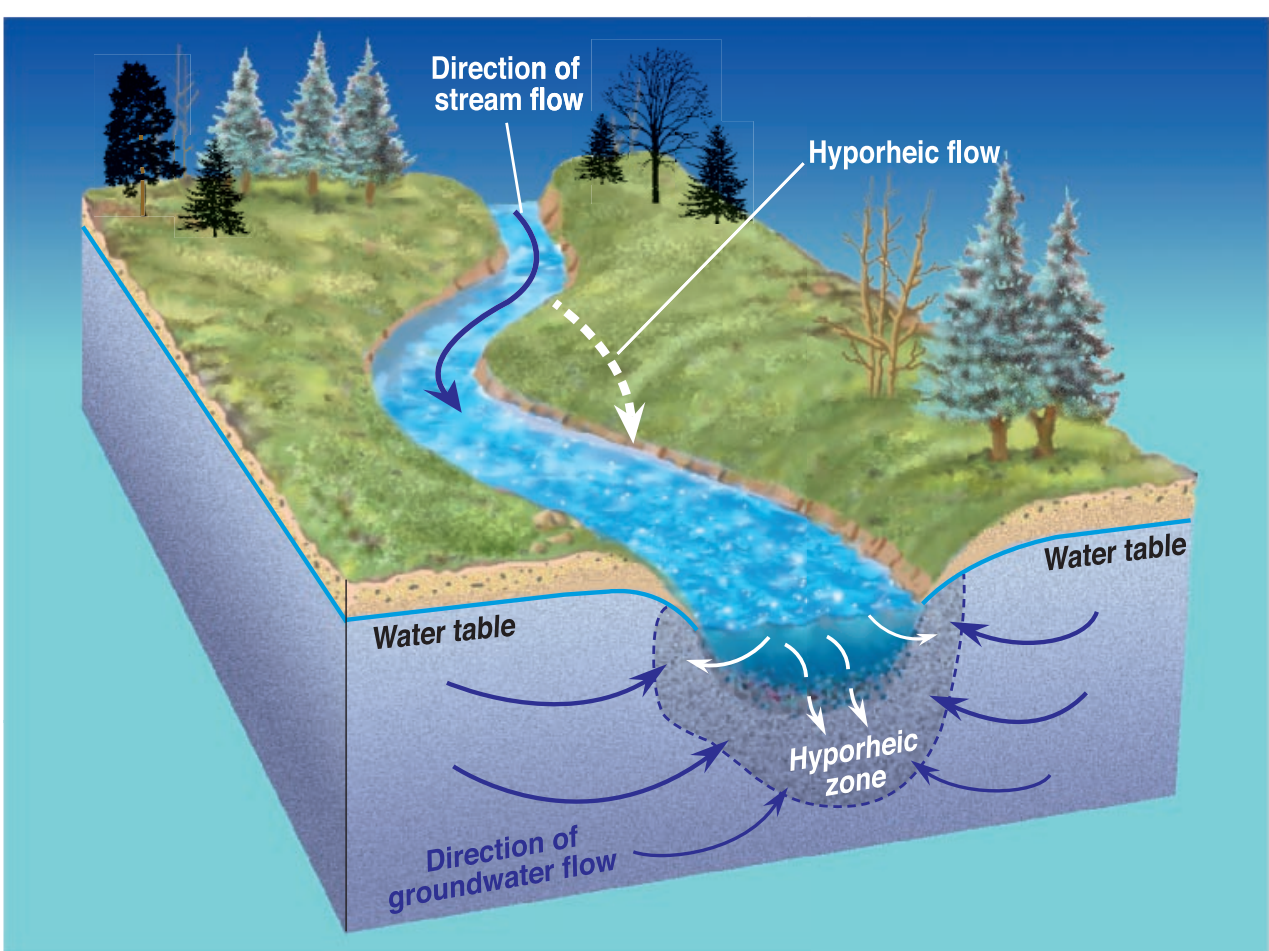

Fig. 4. Local geomorphic features such as stream bed topography, stream bed roughness, meandering, and heterogeneities in sediment hydraulic conductivities can give rise to localized flow systems within stream beds and banks. The near-stream subsurface environment with active exchange between surface water and groundwater commonly is referred to as the hyporheic zone, although the transition between groundwater and surface water represents a hydrologic continuum, preventing a precise separation.

erally quite low and are difficult to measure directly. Measurement of fluxes can be complicated by preferential flow (i.e., macropore or unstable flow) in the unsaturated zone, although preferential flow paths are of greatest concern as potential conduits for rapid contamination of aquifers. The above factors, in addition to temporal and spatial variability, greatly complicate estimation of basin-wide recharge rates. Estimation methods include use of water budgets, tracers, geophysics, and simulation models (34). Recent developments include improved age-dating techniques (23); geophysical monitoring, such as time-domain reflectometry and groundpenetrating radar (35); land- and possibly satellite-based gravity measurements to estimate changes in subsurface water mass over length scales of tens to thousands of $\mathrm{km}(36,37)$; the linking of watershed and groundwater flow models (38); and use of piezometers completed in thick clay layers to measure changing geostatic loads associated with mass changes in subsurface water (39). Because of inherent uncertainties in any method, it is recommended that multiple techniques be applied for any study.

Identifying human practices that influence recharge is straightforward; quantifying effects of these practices is more difficult. Clearing of native vegetation has led to an order of magnitude increase in recharge rates in areas such as the Niger Basin in Africa (32). Irrigation has resulted in increased recharge rates (Fig. 2) as well as salinization of soils and aquifers, such as in the Nile River delta (40). Urbanization has modified natural recharge processes appreciably but does not usually lead to decreased recharge (41), as is often assumed. Enhanced runoff from built-up and paved areas may be channeled to a retention basin or infiltration gallery, resulting in relocation of recharge areas and the transition from slow, diffuse recharge to rapid, localized recharge. Canals, leaky water mains, and sewers are other artifacts of development that influence recharge processes. For example, it is estimated that $26 \%$ of the water transmitted through water mains in Göteborg, Sweden, is lost to leakage (42).

The effects of climate change on recharge also are difficult to assess. Areas of high or low recharge in past climates can perhaps be mapped (43), and groundwaters that infiltrated many thousands of years ago have been identified, but quantification of recharge rates during past climatic periods has been attempted only in isolated arid regions such as the western United States, where, as estimated from tracer data from the unsaturated zone, recharge rates 15,000 years ago were about 20 times the current rates $(44)$.

\section{Interactions with Surface Water}

The interactions of surface-water bodies with groundwater are governed by the positions of the water bodies relative to the groundwater flow system, the characteristics of their beds and underlying materials, and their climatic setting (45). Whereas the geologic framework affects the flow paths through which groundwater flows, the type of sediments at the interface between groundwater and surface water can dictate the spatial variability of discharge to surface water and, in turn, affects the distribution of biota at the interface. For example, silty stream beds with minimal groundwater exchange may support a less diverse suite of biota than do sandy or gravelly stream beds with large groundwater exchange (46). Discharge from springs can provide habitat for unique species that are dependent on adequate groundwater flow (47). In some cases, biota related to groundwater discharge have been used to identify locations where focused discharge occurs into surface waters (48).

Exchange of water across the interface between surface water and groundwater can result from downstream movement of water in and out of stream beds and banks (Fig. 4), tides, wave action, filling or draining of reservoirs, or transpiration of water by vegetation at the edges of wetlands and other surface waters (45). Water exchange across the surface water-groundwater interface has been explored in some detail in the past decade, with most studies focused on streams (49), and is increasingly studied with respect to effects on the chemical composition of surface and subsurface water and the distribution of biota $(46,50)$. Once thought to be of little consequence and thus ignored, the interactions of groundwater with lakes, wetlands, estuaries, and oceans now are recognized as important processes. For example, discharge of saline springs contributes to the salinity of Lake Kinneret, Israel (51); peat wetlands can alternate between recharge and discharge status because of flow reversals (52); coastal groundwater discharge is equivalent to as much as $40 \%$ of riverine input in summer along the coast of South Carolina, USA (53); and groundwater input from the GangesBrahmaputra delta is an important factor affecting the marine strontium isotope record (54).

Thermal effects also play a role in the distribution of biota and biogeochemical processes. For example, thermal effects of groundwater discharge in inland waters have been directly related to fish habitat, both in terms of spawning areas and refuge for adults 


\section{SCIENCE'S COMPASS}

when ice forms in colder environments (55). Thermal differences between groundwater and surface water also are used to provide information on location and amount of recharge (56) and discharge (57), and these data enable indirect determination of geothermal properties of groundwater flow systems, particularly from data gathered at springs (58).

When salt water and fresh water are present, a dynamic interface is present both in the ground and at the discharge boundary of fresh groundwater into salty surface water. In relatively homogeneous porous media, the denser salt water tends to remain separated from the overlying fresh water by a transition zone, known as the zone of diffusion or dispersion. In coastal plain areas where the porous media is heterogeneous in nature, a system of layered mixing zones can form. Advances in geophysical techniques, such as direct-current resistivity and transient electromagnetic induction (59), have enabled better definition of the three-dimensional distribution of salty water in the subsurface.

Large groundwater withdrawals can cause salt water to move into areas of use in coastal (60) and some inland (61) areas and decrease the volume of fresh water available. The important role of fresh groundwater discharge to coastal ecosystems is also increasingly being recognized (62). The time required for the salt water-fresh water interface and freshwater discharge to respond to human and natural changes can range from almost instantaneously to thousands of years. In some coastal areas, such as New Jersey, USA, and Suriname, South America (63), relatively fresh groundwaters located far off the coast are hypothesized to be remaining from the last ice age, when sea levels were much lower.

\section{Interactions with the Land Surface}

When groundwater is removed from storage in groundwater systems, hydraulic heads are lowered, and a portion of the mechanical support for the overlying sediments and subsurface water previously provided by porefluid pressure is transferred to the granular skeleton of the aquifer system. If enough water is withdrawn, the pore-fluid pressure can be reduced enough so that the granular skeleton of the aquifer is irreversibly compressed, causing permanent compaction of the more compressible fine-grained silt and clay layers (aquitards) interbedded within or adjacent to the aquifers. The resulting subsidence can severely damage structures and creates problems in design and operation of facilities for drainage, flood protection, and water conveyance. Examples of areas with large subsidence include the California Central Valley, Houston, and Mexico City (64).

The low permeability of thick aquitards (65) can cause vertical drainage to adjacent pumped aquifers to proceed slowly and to lag far behind changing water levels in these aquifers (Fig. 5). The drainage and compaction in response to a given stress in thick aquitards may require decades or centuries to approach completion. Numerical modeling has successfully simulated complex transient histories of compaction observed in response to measured water-level fluctuations at the site scale (66), but considerable challenges remain at the regional scale to simulate compaction histories of groundwater systems with thick aquitards.

Technologies to measure the sometimes subtle and slow changes in land-surface elevations caused by groundwater withdrawals have evolved considerably from borehole ex-

timing, magnitudes, and patterns of seasonal deformations that may occur in response to seasonal changes in pumping and large-scale artificial recharge (68); have been used to estimate the elastic storage coefficient of an aquifer system at locations where contemporaneous groundwater level observations were available (69); have been used as an observational constraint for inverse modeling of regional groundwater flow and aquifersystem compaction (70); and have provided new insights into how subsidence is controlled by geologic structures and sediment composition (71).

\section{Future Challenges}

Future success in understanding the dynamic nature of groundwater systems will rely on continued and expanded data collection at various scales, improved methods for quantifying heterogeneity in subsurface hydraulic properties, enhanced modeling tools and understanding of model uncertainty, and greater understanding of the role of climate and interactions with surface water.

Water-level measurements from wells remain the principal source of information on the effects of hydrologic stresses on groundwater systems. Advances in instrumentation now enable the collection of real-time water-level data, allowing us to observe diurnal and seasonal trends from well networks across large areas. To understand the true nature of change in a groundwater system and to differentiate between natural and humaninduced changes, we require records of waterlevel measurements over substantial periods (72). Despite their importance, groundwater-level data have received little attention in concerns expressed about the continuity of global water data, primarily because such concerns have focused on more vis-

tensometry and terrestrial geodetic [spirit leveling and Global Positioning System (GPS)] surveys to remote-sensing using space-based radar imaging (64). Interferometric synthetic aperture radar (InSAR) uses repeat radar signals from satellites to measure deformation of Earth's crust at an unprecedented level of spatial detail (changes in elevation on the order of $10 \mathrm{~mm}$ or less) and a high degree of measurement resolution (tens of meters). InSAR results have provided detailed regional maps of land subsidence at seasonal and longer time scales (67); have revealed the ible surface-water monitoring networks (73).

Because aquifers smooth out short-term fluctuations of climate signals, analyses of groundwater systems typically have underplayed the role of climate. Effects of decadalscale fluctuations in wet and dry cycles, such as those hypothesized from the Pacific Decadal Oscillation (74), may have large effects on groundwater systems, but these are relatively unexplored, as are the effects of possible future climate change on the shallow aquifers that supply much of the water in streams, lakes, and wetlands. A greater un- 


\section{SCIENCE'S COMPASS}

derstanding of feedbacks between water levels and atmospheric forcing at seasonal and interannual scales is also needed (20). Because conditions at the time of recharge influence the geochemical composition of water percolating into the subsurface, aquifers may prove to be invaluable archives of past climate and environmental change (75).

Surface-water depletion is viewed increasingly as the limiting factor to the longterm use of groundwater resources, yet the distinctly different temporal and spatial scales at which groundwater and surfacewater systems operate present major challenges to their integrated analysis. The locations, quantity, and timing of reductions in surface-water flow resulting from groundwater development are fundamental questions at scales of years to decades, whereas ecological issues require attention to seasonal and even diurnal changes in groundwater recharge and discharge and more attention to fluvial plain and channel-scale flow processes (76).

Groundwater systems have value not only as perennial sources of water supply, but also as reservoirs for cyclical injection and withdrawal to modulate the variability inherent in surface-water supplies. Management approaches increasingly involve the use of artificial recharge of excess surface water or recycled water by direct well injection, surface spreading, or induced recharge from streams. As predictive links between hydrology and climate improve (e.g., prediction of El Niño conditions), opportunities exist to make better use of the storage capacity of groundwater systems. Many scientific challenges remain to understand more fully the long-term hydraulic response of aquifer systems, subsurface chemical and biological changes of the injected water, and geochemical effects of mixing waters of different chemistries (77). With time and extensive use, much of the local groundwater may be derived from artificial recharge (78) - a further indicator of the dynamic nature of groundwater systems.

\section{References and Notes}

1. R. Clarke, A. Lawrence, S. Foster, Groundwater: A Threatened Resource (United Nations Environment Programme Environment Library No. 15, Nairobi, Kenya, 1996).

2. W. B. Solley, R. R. Pierce, H. A. Perlman, U.S. Geol. Surv. Circ. 1200 (1998).

3. S. Postel, Pillar of Sand: Can the Irrigation Miracle Last? (Norton, New York, 1999).

4. D. L. Sahagian, F. W. Schwartz, D. K. Jacobs, Nature 367, 54 (1994).

5. Schwartz and Ibaraki (79) provide evidence of the maturing nature of groundwater hydrology as a distinct field. This implies that the greatest future advances are likely to be in integration with other fields.

6. H. W. Bentley et al., Water Resour. Res. 22, 1991 (1986).

7. The "age" of water usually refers to the amount of time since the water entered the top boundary of the saturated system or water table. Depending on the age-dating technique, it may have other meanings, such as the amount of time since the water entered at the land surface.
8. P. A. Domenico, F. W. Schwartz, Physical and Chemical Hydrogeology (Wiley, New York, 1998).

9. Equation 1 is for a homogeneous, confined, constant density groundwater basin and is derived from the diffusion equation [(8), p. 72]. The system representative of horizontal flow in a confined stream-aquifer system, the lower aquifer of the Mississippi River alluvium in lowa (80), has a characteristic length of $1000 \mathrm{~m}$ and a hydraulic conductivity of $10 \mathrm{~m} /$ day. The system representative of vertical flow in a thick regional low-permeability unit, the Pierre Shale in North Dakota (81), has a characteristic length of $200 \mathrm{~m}$ and a hydraulic conductivity of $10^{-9} \mathrm{~m} /$ day. A specific storage of $10^{-6} \mathrm{~m}^{-1}$ was assumed to be representative of both systems.

10. The time of travel for the confined, stream-aquifer system $(80)$ is obtained by dividing the characteristic length of $1000 \mathrm{~m}$ by the velocity of the fluid movement. The velocity $(v)$ of the fluid movement is calculated by dividing Darcy's law by a porosity $(n)$ of 0.3 , assuming a representative uniform head gradient (i) of $0.001(v=K i / n)$.

11. Rock Fractures and Fluid Flow (National Academy of Sciences, Washington, DC, 1996).

12. T. W. Rayne, K. R. Bradbury, M. A. Muldoon, Hydrogeol. J. 9, 432 (2001).

13. W. E. Sanford, S. Buapeng, Hydrogeol. J. 4, 26 (1996).

14. G. Garven, Annu. Rev. Earth Planet. Sci. 23, 89 (1995).

15. B. J. O. L. McPherson, J. D. Bredehoeft, Water Resour. Res. 37, 857 (2001).

16. B. W. Bruce, G. P. Oelsner, J. Am. Water Res. Assoc. 37, 1389 (2001).

17. J. D. Bredehoeft, S. S. Papadopulos, H. H. Cooper Jr., in Scientific Basis of Water Resources Management (National Academy Press, Washington, DC, 1982), pp. 51-57.

18. W. M. Alley, T. E. Reilly, O. L. Franke, U.S. Geol. Surv. Circ. 1186 (1999).

19. D. A. Sverjensky, G. Garven, Nature 356, 481 (1992).

20. J. P. York, M. Person, W. J. Gutowski, T. C. Winter, Adv. Water Resour. 25, 221 (2002).

21. P. Lichtner, C. Steefel, E. Oelkers, Eds., special issue on Reactive Transport in Porous Media, Rev. Mineral. 34 (1996).

22. E. P. Poeter, M. C. Hill, Ground Water 35, 250 (1997).

23. P. G. Cook, J.-K. Böhlke, in Environmental Tracers in Subsurface Hydrology, P. G. Cook, A. L. Herczeg, Eds. (Kluwer, Boston, 1999), pp. 1-30.

24. P. G. Cook, D. K. Solomon, J. Hydrol. 191, 245 (1997). 25. L. N. Plummer et al., Appl. Geochem. 13, 995 (1998).

26. T. E. Reilly, L. N. Plummer, P. J. Phillips, E. Busenberg, Water Resour. Res. 30, 421 (1994).

27. Z. Top, L. E. Brand, R. D. Corbett, W. Burnett, J. Chanton, J. Coastal Res. 17, 859 (2001).

28. A. M. Shapiro, Water Resour. Res. 37, 507 (2001).

29. W. Edmunds, S. Tyler, Hydrogeol. J. 10, 216 (2002).

30. A. L. Flint, L. E. Flint, E. M. Kwicklis, G. S. Bodvarsson, J. M. Fabryka-Martin, Rev. Geophys. 39, 447 (2001).

31. D. N. Lerner, A. S. Issar, I. Simmers, Groundwater Recharge, vol. 8 of International Association of Hydrogeologists, International Contributions to Hydrogeology (Heise, Hannover, West Germany, 1990).

32. G. Favreau et al., Ground Water 40, 144 (2002).

33. M. Sophocleous, J. Hydrol. 137, 113 (1992).

34. B. R. Scanlon, R. W. Healy, P. G. Cook, Hydrogeol. J. 10, 18 (2002).

35. J. A. Huisman, C. Sperl, W. Bouten, J. M. Verstraten, J. Hydrol. 245, 48 (2001).

36. D. R. Pool, J. H. Eychaner, Ground Water 33, 425 (1995).

37. J. Wahr, M. Molenaar, F. Bryan, J. Geophys. Res. 103, 30205 (1998).

38. M. Sophocleous, S. P. Perkins, J. Hydrol. 236, 185 (2000).

39. G. van der Kamp, R. Schmidt, Geophys. Res. Lett. 24, 719 (1997).

40. T. H. S. Kotb, K. K. Tanji, T. Watanabe, Y. Ogino, Agric. Water Manage. 43, 239 (2000).

41. D. N. Lerner, Hydrogeol. J. 10, 143 (2002).

42. M. Norin, A-M. Hulten, C. Svensson, in Groundwater in the Urban Environment-Selected City Profiles, J. Chilton, Ed. (Balkema, Rotterdam, 1999), pp. 209216.

43. U. Beyerle et al., Science 282, 731 (1998).
44. F. M. Phillips, Soil Sci. Soc. Am. J. 58, 15 (1994)

45. T. C. Winter, J. W. Harvey, O. L. Franke, W. M. Alley, U.S. Geol. Surv. Circ. 1139 (1998).

46. P. Marmonier et al., in Subterranean Ecosystems, $\mathrm{H}$. Wilkens, D. C. Culver, W. F. Humphreys, Eds., vol. 30 of Ecosystems of the World (Elsevier, Amsterdam, 2000), pp. 513-531.

47. J. M. Sharp Jr., J. L. Banner, in The Earth Around Us: Maintaining a Livable Planet, J. L. Schneiderman, Ed. (Freeman, New York, 2000), pp. 154-165.

48. D. O. Rosenberry, R. G. Striegl, D. L. Hudson, Ground Water 38, 296 (2000).

49. J. A. Jones, P. J. Mulholland, Eds., Streams and Groundwater (Academic Press, San Diego, CA, 2000).

50. A. J. Boulton, Ecosyst. Health 6, 108 (2000).

51. R. J. G. Mortimer, M. D. Krom, D. R. Boyle, A. Nishri, Limnol. Oceanogr. 44, 1802 (1999).

52. C. J. D. Fraser, N. T. Roulet, M. Laffleur, J. Hydrol. 246, 142 (2001).

53. W. S. Moore, Mar. Chem. 65, 111 (1999).

54. A. R. Basu, S. B. Jacobsen, R. J. Poreda, C. B. Dowling, P. K. Aggarwal, Science 293, 1470 (2001)

55. G. Power, R. S. Brown, J. G. Imhof, Hydrol. Proc. 13, 401 (1999).

56. J. Constantz, Water Resour. Res. 34, 1609 (1998).

57. F. Malard, A. Mangin, U. Uehlinger, J. V. Ward, Can. J. Fish. Aquat. Sci. 58, 1319 (2001)

58. M. Manga, Annu. Rev. Earth Planet. Sci. 29, 201 (2001).

59. C.-H. Yang, L.-T. Tong, G.-F. Huang, Geophysics 64, 417 (1999).

60. J. Bear, A. H.-D. Cheng, S. Soreck, D. Ouazar, I. Herrera, Eds., Seawater Intrusion in Coastal AquifersConcepts, Methods, and Practices (Kluwer, Dordrecht, Netherlands, 1999).

61. T. D. Lahm, E. S. Bair, Water Resour. Res. 36, 3167 (2000).

62. J. Laroche et al., Global Change Biol. 3, 397 (1997).

63. H. Kooi, J. Groen, J. Hydrol. 246, 19 (2001).

64. D. Galloway, D. R. Jones, S. E. Ingebritsen, Eds., U.S. Geol. Surv. Circ. 1182 (1999).

65. Equation 1 can provide an indication of the time required for the excess pore pressure to dissipate after an instantaneous change in head at the boundaries of an aquitard by substituting the aquitard values for hydraulic conductivity, specific storage, and thickness (divided by 2 for doubly draining aquitard).

66. M. Sneed, D. L. Galloway, U.S. Geol. Surv. Water Res. Invest. Rep. 00-4015 (2000).

67. D. L. Galloway et al., Water Resour. Res. 34, 2573 (1998).

68. G. W. Bawden, W. Thatcher, R. S. Stein, K. W. Hudson, G. Peltzer, Nature 412, 812 (2001).

69. J. Hoffmann, H. A. Zebker, D. L. Galloway, F. Amelung, Water Resour. Res. 37, 1551 (2001).

70. J. Hoffmann, D. L. Galloway, H. A. Zebker, Eos 82 no. (47), abstract H41E-0320 (2001).

71. F. Amelung, D. L. Galloway, J. W. Bell, H. A. Zebker, R. L. Laczniak, Geology 27, 483 (1999).

72. C. J. Taylor, W. M. Alley, U.S. Geol. Surv. Circ. 1217 (2001).

73. C. J. Vörösmarty et al., Eos 82, 54 (2001).

74. J. N. Mantua, S. R. Hare, Y. Zhang, J. M. Wallace, R. C. Francis, Bull. Am. Meteorol. Soc. 78, 1069 (1997).

75. H. H. Loosli et al., Eos 79, 576 (1998).

76. W. W. Woessner, Ground Water 38, 423 (2000)

77. Aquifer Storage and Recovery in the Comprehensive Everglades Restoration Plan (National Academy of Sciences, Washington, DC, 2001).

78. J. L. Shelton et al., U.S. Geol. Surv. Water Resour. Invest. Rep. 01-4188 (2001).

79. F. W. Schwartz, M. Ibaraki, Ground Water 39, 492 (2001).

80. R. A. Boyd, U.S. Geol. Surv. Water Resour. Invest. Rep. 00-4274 (2001).

81. C. E. Neuzil, Water Resour. Res. 29, 2007 (1993).

82. W. H. Schlesinger, in Biogeochemistry-An Analysis of Global Change (Academic Press, San Diego, CA, ed. 2, 1997), chapter 10.

83. R. H. Johnston, U.S. Geol. Surv. Prof. Pap. 1425 (1997).

84. We thank A. J. Boulton, L. F. Konikow, A. M. Shapiro, E. P. Weeks, T. C. Winter, and an anonymous reviewer for insightful comments and suggestions. 